\title{
Exploring Undergraduates' Judgements on the Qualities of Corrective Feedback for English Pronunciation Errors
}

\author{
Zulqarnain Abu Bakar ${ }^{1}$, Abdul Mutalib Embong ${ }^{2}$ \\ ${ }^{1}$ Department of Management \& Humanities, Universiti Teknologi Petronas, Bdr Seri Isknadar, Perak, Malaysia \\ ${ }^{2}$ Department of Management \& Humanities, Universiti Teknologi Petronas, Bdr Seri Isknadar, Perak, Malaysia
}

\begin{abstract}
The present study is an investigative work to examine learners' judgements on some proposed error correction methods, in connection with mispronounced English words. Learners are to evaluate the qualities of six different types of correction approaches, in terms of 'embarrassment', 'comprehensibility' and 'effectiveness' through a set of 36 error-correcting-act video clips representing the six correction types. A set of corresponding questionnaire survey in exploring respondents' insights was administered. Comparisons by their learning experience (year) and environment (institution) were carried out to study any effect on their judgements. The results of the survey conducted on 88 undergraduate students revealed that the respondents seem to share the same pattern of observations despite their learning experience and types of higher institutions. They have concern on the aspect of 'embarrassment' in relation to all corrective feedback types except for Repetition and Clarification Requests which are more communicative in their approach.
\end{abstract}

\section{Introduction}

Pronunciation skill has been the concern of many language learners, particularly to those who are learning a target language that shares very minimal similarity to the inventory of their first language (L1) sounds system. Being able to communicate in a target language, simply means that one is orally competent to speak and understand basic utterances of the language. The ability to produce the correct sound, pronounce meaningful words and phrases, and communicate for basic needs in the target language besides reading and writing, would boost learners' confidence to explore further and eventually master the language in question. Such description applies to all language learning scenario for whatever purposes. For one thing, learners and teachers of English as the Second Language (ESL) programs are concerned on the accuracy of the target pronunciation. Thus, attention on the guide to improve target pronunciation is paramount. However, the focus on pronunciation had been perceived as pointless by many ESL practitioners in the past (Chomsky, 1959; Krashen,1982,1985,1994). Pronunciation research became unpopular and was neglected due to the beliefs that learners will not be able to acquire native-like speech (Celce-Murcia, Brinton \& Goodwind, 1996; Dalton \& Seidlhofer, 2000). This aspect of language proficiency was neglected for teachers were skeptical of the right direction to follow in guiding their students. Researches on teaching pronunciation were close to none till the late 1990's. On the other hand, the interest in improving pronunciation is close to the hearts of the learners who inspire to speak the target language fluently (Abu Bakar \& Abdullah, 2015). The strong concern on pronunciation training started to gain researchers' attention in early 2000's (Murphy \& Baker, 2015) as well as Saito and Lyster (2012) compiled and studied several pronunciations training oriented classrooms to understand closely what take place during pronunciation-focused activities. Undoubtedly, there are numerous issues that requires experts' scrutiny in relation to enhance the impact of pronunciation training, in relation to teaching delivery, corrective feedback, attention, consciousness and awareness to name a few.

Similar to feedback on errors committed in other mechanics of a language, like grammar, vocabulary and writing, feedback on pronunciation errors is believed to be practical and applicable in assisting learners making adjustment towards the target accuracy (Neri, Cucchiari \& Strick, 2001). In other words, it acts as a mechanism to raise learners' awareness on the target forms that they have been exposed to (Ellis, 2001; Ellis, Basturkmen \&Lowen, 2001). Levelt (1989), in his model of speech production, theorizes that every learner is equipped with a support, what he termed as 'perceptual loop of monitoring'. The loop functions as a monitoring 'device' that evaluates the accuracy of a speaker's

\footnotetext{
*Corresponding author: zulqab@utp.edu.my
} 
utterances. Upon self-realizing the mispronounced word, the speaker's knowledge on the inventory of the sound system will be triggered, the intended sound will be retrieved and the reformulation of the correct, intended sound takes place. The same principle can be applied in the pronunciation teaching and learning environment. However, instead of getting signals that triggered from the built-in parser which may not be readily functioning automatically as in the L1 system, an external assistance through corrective feedback can be utilized to raise learner's attention on the error committed. The learner will then retrieve the corresponding sound and make the correction accordingly (Abu Bakar, 2008). Lyster and Ranta (1997) who believe in the utilization of corrective feedback in response to a learner's errors, proposed six types of mechanisms to assist learners in adjusting toward the target forms of a language point in question. The six suggested corrective feedback types for the errors are Explicit correction, Clarification Request, Verbal Metalinguistic Feedback, Elicitation, Repetition and Recast. Recast, however has been perceived to have a very low tendency of learner uptake due to its ambiguity and subtleness to the extent that a learner may miss the corrective move (Lyster \& Ranta, 1997). In the current study, Recast is not considered as a potential corrective move that may be practically applicable. Thus, it is not adopted as one of the corrective feedback types in the current study. Another form of corrective feedback used in many pronunciation workbooks is Visual Cue (Celce-Murcia, Brinton \& Goodwind, 1996). This is another alternative form of corrective move that may be potentially applicable in the context of the current study. The following examples of the different corrective feedback types have been adopted and adapted to suit the application in the context of pronunciation training environment in the study as illustrated by Abu Bakar (2008).

Explicit Correction refers to the explicit provision of the target form. This is the type in which the instructor provides the correct form and clearly indicates the inaccuracy of a particular utterance.

\section{Example:}

Instructor: “...er not 'viskers', it's 'whiskers'...”

Here consciousness and attention are activated through auditory or external loop monitoring (Levelt, 1989). The auditory feedback gives the learner the opportunity to tune in to the whole pronunciation of the words and make a comparison between target and non-target pronunciation. As consciousness and attention are triggered, the target phoneme is retrieved, and the intended production is reformulated.

Clarification Requests indicates to the learner that the instructor has misunderstood his or her pronunciation due to the ill-formed pronunciation in some way and a reformulation is required.

\section{Example:}

Instructor: “... Sorry, what do you mean by flower base?” (as opposed to 'vase')

Here the non-target sound is highlighted to trigger the learner's consciousness and attention (Schmidt, 1990). The target phoneme is retrieved, and the word is reformulated.

Verbal metalinguistic feedback may contain comments, information or questions related to the well-formedness of the learner's utterance, without giving the explicit correct form of the pronunciation. Metalinguistic reference is employed to guide the learner by first implying that there is an error somewhere in the word or phrase.

\section{Example:}

Instructor: “...no...no...no, is that how you pronounce it?... should it be with the long or short vowel?"

In this type of feedback, the learner's consciousness and attention are drawn toward the metalinguistic knowledge related to the phoneme in focus. Upon realization of the discrepancy, the target phoneme is retrieved, and the target word is reformulated.

Elicitation refers to steps that the instructor employs to indirectly elicit the correct form of the pronunciation. First, the instructor elicits the completion of his or her own utterance by strategically pausing to allow learners to "fill in the blank". 


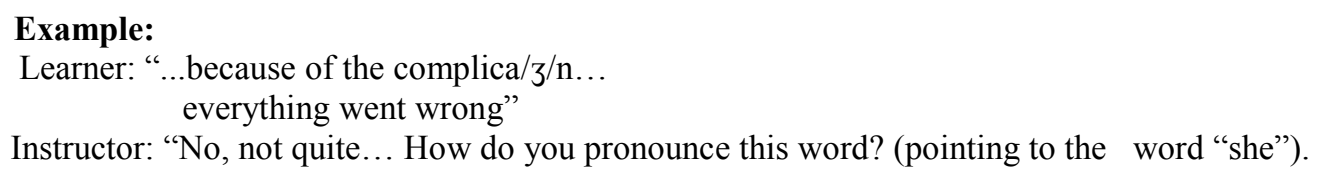

The target sound is $/ \int /$ in "complication". The elicit completion moves may be led by a metalinguistic comment e.g. "No, not voiced..." Next, the instructor uses a question, hinting at a clue that relates to the learner's prior knowledge e.g., "How do you pronounce this word (pointing to the word "she"). Then, the instructor may ask the learner to reformulate his or her utterance. In this type of feedback, consciousness and attention are triggered by the rising tone preceding the problematic pronunciation. The highlighting of a common word in which the target phoneme exists takes place and the target phoneme is then retrieved, and the production reformulated.

Repetition refers to the instructor's duplication in isolation of the learner's erroneous pronunciation. This may be done by adjusting the intonation to highlight the error.

\section{Example:}

Learner: "the /kpmplikt/ (as opposed to 'conflict') is due to..." Instructor: "the /kpmplikt/?

The instructor repeats "the /knmplikt/?" with rising tone of voice indicating puzzlement. Here consciousness and attention are triggered by reinforcement of the non-target production. In response, based on the learner's prior knowledge, the target phoneme is retrieved and the target production reformulated.

Visual Cues refers to a type of feedback, based on the use of visual aids in pronunciation workbooks and software. The instructor directs the learner's attention to the visual representation of the segment in question.

\section{Example:}

Learner: ...they have booked the /hctel/ (as opposed to 'hotel').

Instructor: take a look at this (showing the cross-sectional view of the articulatory system depicting the vowel trapezium at the same time the target phoneme is uttered) .../houtel/

Error corrective feedback is one of the aspects in language training that has also been the interest of ESL researchers who believe that accuracy can be improved, given proper input and guidance in assisting learners to make adjustment (Lyster \& Ranta, 1997; Ellis, 2001). However, the question is on how do learners perceive the qualities and judge the corrective feedback they receive in their experience, trying to enhance their performance.

A clear input in a lesson or instruction, naturally should be supported by an equally clear corrective move to facilitate learning. An error feedback will serve no purpose if it is not received and responded for the intended purposes accordingly. In other words, it should be provided, for one thing, with clear comprehensibility to ensure that learner understands the intervention and reacts with the appropriate reformulation (Ellis,2017; Price, Handley, Millar \& O'Donovan, 2010; Poulos \& Mahony, 2008). A learner needs to understand what has gone wrong before being able to provide the targeted output as desired. In the case for pronunciation training, the corrective move has to be clearly referred to the problematic sound as to avoid mistaken interpretation of the intervention. For example, a learner may mistakenly perceive a corrective feedback meant for a problematic sound in a target pronunciation to the choice of vocabulary used in the utterance. This will result in a mismatch in the response, contrary to the desired output.

Another aspect of corrective feedback that is considered vital as identified by Poulos and Mahony (2008) is effectiveness. This aspect of quality in corrective feedback deals with the way learners feel about the approach in the feedback provided and the believes in its workability in terms of the mannerism or how the corrective move is delivered to them. Naturally, a receiver of any corrective feedback would be able to experience if the assistance provided is in fact useful. Effective correction moves promote positive attitude towards improving one's targeted output (Vanosfadrani \& Basturkment, 2009). 
Face-saving and embarrassment are very vital to be considered in corrective feedback moves, particularly in the context of adult learning. A corrective feedback that is perceived to be disconcerting may not serve its purpose to assist learners making adjustment in the target output. It may deter learner's focus and confidence instead (Agudo \& de Dios, 2013). A study conducted by Lasabagaster and Sierra (2005) on a big group of ESL learners revealed that learners may be disturbed by embarrassment, following a corrective feedback perceived to be jeopardizing learners' face.

Considering the aspect of qualities and judgements on the different corrective feedback types, the study seeks to accomplish the following objectives:

1. To elicit the learners' overall understandings of the different qualities in the different corrective feedback types

2. To elicit the learners' assessments on the qualities of the different corrective feedback types based on their learning experience

3. To elicit learners' assessments on the qualities of the different corrective feedback types based on and their learning environments

4. To elicit the learners' specific concern on the qualities of the corrective feedback types

Findings from these objectives will provide learners' perspectives on the qualities and judgements they have towards the different error correction types in questions.

\section{Method}

A set of survey questionnaire, corresponding to 36 corrective feedback video clips was employed to observe learners' assessment on 'Comprehensibility', 'Effectiveness' and 'Embarrassment', i.e., the qualities or the evaluation criteria in relation to the six different corrective feedback types. The matrix below summarizes the design of the questionnaire.

Table 1.0 Matrix of error correction types and evaluation criteria in relation to phonemes

\begin{tabular}{|c|c|c|c|c|c|c|}
\hline \multirow{2}{*}{$\begin{array}{l}\text { Error } \\
\text { Correction } \\
\text { Type }\end{array}$} & \multicolumn{6}{|c|}{ Evaluation Criteria } \\
\hline & \multicolumn{2}{|c|}{$\begin{array}{c}\text { Comprehensibility } \\
\text { (X) }\end{array}$} & \multicolumn{2}{|c|}{$\begin{array}{c}\text { Embarrassment } \\
(\mathrm{Y})\end{array}$} & \multicolumn{2}{|c|}{$\begin{array}{c}\text { Effectiveness } \\
\text { (Z) }\end{array}$} \\
\hline \multirow{2}{*}{ Explicit Correction } & $*[\mathrm{I}]$ & [th] & [o] & [zh] & [e] & {$[\mathrm{sh}]$} \\
\hline & C1X & $\mathrm{C} 33 \mathrm{X}$ & $\mathrm{C} 35 \mathrm{Y}$ & $\mathrm{C} 26 \mathrm{Y}$ & $\mathrm{C} 30 \mathrm{Z}$ & $\mathrm{C} 21 \mathrm{Z}$ \\
\hline \multirow[t]{2}{*}{ Visual Cues } & [e] & {$[\mathrm{sh}]$} & {$[\mathrm{I}]$} & [th] & [o] & [zh] \\
\hline & $\mathrm{C} 25 \mathrm{X}$ & $\mathrm{C} 34 \mathrm{X}$ & $\mathrm{C} 7 \mathrm{Y}$ & $\mathrm{C} 29 \mathrm{Y}$ & $\mathrm{C} 32 \mathrm{Z}$ & $\mathrm{C} 2 \mathrm{Z}$ \\
\hline \multirow[t]{2}{*}{ Clarification Request } & [o] & [zh] & [e] & {$[\mathrm{sh}]$} & [I] & [th] \\
\hline & C28X & $\mathrm{C} 8 \mathrm{X}$ & $\mathrm{C} 3 \mathrm{Y}$ & $\mathrm{C} 31 \mathrm{Y}$ & $\mathrm{C} 12 \mathrm{Z}$ & $\mathrm{C} 24 \mathrm{Z}$ \\
\hline \multirow[t]{2}{*}{ V. M. Feedback } & {$[\mathrm{I}]$} & {$[\mathrm{th}]$} & {$[\mathrm{o}]$} & {$[\mathrm{zh}]$} & {$[\mathrm{e}]$} & {$[\mathrm{sh}]$} \\
\hline & C16X & $\mathrm{C} 4 \mathrm{X}$ & $\mathrm{C} 23 \mathrm{Y}$ & $\mathrm{C} 13 \mathrm{Y}$ & C9Z & $\mathrm{C} 27 \mathrm{Z}$ \\
\hline \multirow[t]{2}{*}{ Elicitation } & [e] & [sh] & {$[\mathrm{I}]$} & {$[\mathrm{th}]$} & [o] & {$[\mathrm{zh}]$} \\
\hline & $\mathrm{C} 14 \mathrm{X}$ & $\mathrm{C} 22 \mathrm{X}$ & $\mathrm{C} 19 \mathrm{Y}$ & $\mathrm{C} 10 \mathrm{Y}$ & $\mathrm{C} 5 \mathrm{Z}$ & $\mathrm{C} 17 \mathrm{Z}$ \\
\hline \multirow{2}{*}{ Repetition } & [o] & [zh] & [e] & {$[\mathrm{sh}]$} & {$[\mathrm{I}]$} & [th] \\
\hline & $\mathrm{C} 11 \mathrm{X}$ & $\mathrm{C} 20 \mathrm{X}$ & $\mathrm{C} 18 \mathrm{Y}$ & C6Y & C $36 Z$ & C15Z \\
\hline
\end{tabular}

Table 1.0 also shows the labels used for each clip in the video compact disk (VCD); these correspond with the item statements in the questionnaire form, in which, for example, [th] represents the phoneme in question, "Z" represents the qualities or evaluation criteria addressed in the statement, in this case "effectiveness", and "C15" denotes clip number 15. There were 88 respondents of the first and final year students representing two institutions. One institution employs a totally English instruction in class deliveries, while the other is in mixed environment in which instructions 
are delivered in both English and the mother tongue (Malay language). The Cronbach Alpha coefficient for all items of the questionnaire survey is 0.801 , a value of high reliability.

\section{Findings and Discussions}

A total of 3168 assessments were recorded as each of the 88 respondents evaluated 36 clips. 38 males and 50 female students from institution A (total English environment) and institution B (a mixed English-Malay environment) respectively, representing the first and final year students completed the evaluation in a lab provided. Learners' responses were analysed through descriptive statistics and the Ducan Post Hoc tests.

In response to the objectives of the study to assess the learners' judgements on the qualities of the different types of corrective feedback, the results revealed quite similar results at all levels.

\section{Overall understanding on the different qualities}

In response to first objective of the study, the analysis on the qualities or evaluation criteria show that learners seem to have the overall understanding on the qualities of all the corrective feedback types. The p-value for all the correction types are significant, suggesting that learners could see clear differences in the qualities for each of the corrective feedback types, except for Repetition. In other words, they have clear idea on how the different qualities function or work in the different manners of corrections. In the case of Repetition, the judgement on the qualities are somewhat equal with the p-value of 0.703 , which is not significant. Though the ratings seem to be positive with relatively strong means, "embarrassment" is seen to be the most concerned qualities among the learners as depicted from all Duncan Post Hoc tests for all types of corrective feedback, except for Clarification Request with which "comprehensibility" is the major concern.

Table 1.1 summarizes the learners' judgments on the qualities or evaluation criteria in relation to all corrective feedback types, showing the comparison between "comprehensibility", "embarrassment" and "effectiveness". 
Table 1.1 General mean scores, standard deviation and significant difference of respondents' assessment in relation to the evaluation criteria using one-way ANOVA

\begin{tabular}{|c|c|c|c|c|c|}
\hline Correction Type & Evaluation Criteria & Mean & $\mathbf{N}$ & $\begin{array}{c}\text { Std. } \\
\text { Deviation }\end{array}$ & p-value \\
\hline Visual cues & $\begin{array}{l}\text { comprehensibility } \\
\text { embarrassment } \\
\text { effectiveness } \\
\text { Total }\end{array}$ & $\begin{array}{l}1.87 \\
2.13 \\
1.89 \\
1.96\end{array}$ & $\begin{array}{l}176 \\
176 \\
176 \\
\\
528\end{array}$ & $\begin{array}{l}.894 \\
.898 \\
.897 \\
.902\end{array}$ & $.013^{*}$ \\
\hline $\begin{array}{l}\text { Explicit } \\
\text { Correction }\end{array}$ & $\begin{array}{l}\text { comprehensibility } \\
\text { embarrassment } \\
\text { effectiveness } \\
\text { Total }\end{array}$ & $\begin{array}{l}1.90 \\
2.18 \\
1.63 \\
1.90\end{array}$ & $\begin{array}{l}176 \\
176 \\
176 \\
528\end{array}$ & $\begin{array}{l}.856 \\
1.094 \\
.663 \\
.915\end{array}$ & $<0.0001^{*}$ \\
\hline Elicitation & $\begin{array}{l}\text { comprehensibility } \\
\text { embarrassment } \\
\text { effectiveness } \\
\text { Total }\end{array}$ & $\begin{array}{l}2.07 \\
2.28 \\
1.94 \\
2.10\end{array}$ & $\begin{array}{l}176 \\
176 \\
176 \\
528\end{array}$ & $\begin{array}{r}.950 \\
.919 \\
.863 \\
.921\end{array}$ & $.002 *$ \\
\hline $\begin{array}{l}\text { Verbal } \\
\text { Metalinguistic } \\
\text { Feedback }\end{array}$ & $\begin{array}{l}\text { comprehensibility } \\
\text { embarrassment } \\
\text { effectiveness } \\
\text { Total }\end{array}$ & $\begin{array}{l}2.33 \\
2.66 \\
2.13 \\
2.37\end{array}$ & $\begin{array}{l}176 \\
176 \\
176 \\
528\end{array}$ & $\begin{array}{l}.971 \\
.995 \\
.812 \\
.954\end{array}$ & $<0.0001 *$ \\
\hline Repetition & $\begin{array}{l}\text { comprehensibility } \\
\text { embarrassment } \\
\text { effectiveness } \\
\text { Total }\end{array}$ & $\begin{array}{l}2.60 \\
2.68 \\
2.68 \\
2.65\end{array}$ & $\begin{array}{l}176 \\
176 \\
176 \\
528\end{array}$ & $\begin{array}{c}1.075 \\
.998 \\
1.117 \\
1.063\end{array}$ & .703 \\
\hline $\begin{array}{l}\text { Clarification } \\
\text { Requests }\end{array}$ & $\begin{array}{l}\text { comprehensibility } \\
\text { embarrassment } \\
\text { effectiveness } \\
\text { Total }\end{array}$ & $\begin{array}{l}3.03 \\
2.76 \\
2.80 \\
2.86\end{array}$ & $\begin{array}{l}176 \\
176 \\
176 \\
528\end{array}$ & $\begin{array}{l}1.039 \\
1.008 \\
1.071 \\
1.044\end{array}$ & $.033^{*}$ \\
\hline
\end{tabular}

* Significant at the 0.05 level

Note: $1=$ strongly agree, 2 = agree, $3=$ neutral, 4 = disagree, $5=$ strongly disagree

A high mean indicates a less positive attitude and a low mean indicates a more positive attitude

\section{Assessments on the qualities of the different corrective feedback types by learning experience}

In relation to the learners' assessments on the qualities based on their learning experience, i.e., in terms of duration of time they have spent studying at tertiary level, results show that both, the first and final year students from the two institutions seem to share almost similar concerns. Contrasting with the overall results in which learners showed clear judgements on most of the corrective feedback with regards to the qualities, in comparison with regards to the duration on their learning experience, the results revealed that both sets of learners showed almost similar concerns on Explicit Correction and Verbal Metalinguistics Feedback. The final year students also seem to have clear judgement in relation to Elicitation. The results seem to suggest that both groups perceive all the qualities of the corrective feedback types with almost equally similar concerns in terms of their understanding for all the corrective feedback types except for Explicit Correction and Verbal Metalinguistic Feedback, with which "embarrassment" remains as the most concerned qualities for all corrective feedback types. Table 1.2 summarizes both the first and final year learners' judgements on the qualities of all the corrective feedback types. 
Table 1.2 Mean scores, standard deviation and significance for correction type in relation to the evaluation criteria by year

\begin{tabular}{|c|c|c|c|c|c|c|c|c|c|c|c|}
\hline \multicolumn{6}{|c|}{ First Year } & \multicolumn{6}{|c|}{ Final Year } \\
\hline $\begin{array}{l}\text { Cor. } \\
\text { Typ. }\end{array}$ & $\begin{array}{c}\text { Evaluation } \\
\text { Criteria }\end{array}$ & Mean & $\mathbf{N}$ & $\begin{array}{l}\text { Std. } \\
\text { Dev. }\end{array}$ & $\begin{array}{c}p- \\
\text { value }\end{array}$ & $\begin{array}{l}\text { Cor. } \\
\text { Typ. }\end{array}$ & $\begin{array}{c}\text { Evaluation } \\
\text { Criteria }\end{array}$ & Mean & N & $\begin{array}{l}\text { Std. } \\
\text { Dev. }\end{array}$ & $\begin{array}{c}\mathrm{p}- \\
\text { value }\end{array}$ \\
\hline \multirow{4}{*}{ vSC } & comprehensibility & 1.85 & 86 & .901 & .095 & \multirow{4}{*}{ VSC } & \multirow{4}{*}{$\begin{array}{l}\text { comprehensibility } \\
\text { embarrassment } \\
\text { effectiveness } \\
\text { Total }\end{array}$} & 1.89 & 90 & .892 & \multirow[t]{4}{*}{.131} \\
\hline & embarrassment & 2.14 & 86 & .922 & & & & 2.11 & 90 & .880 & \\
\hline & effectiveness & 1.91 & 86 & .953 & & & & 1.88 & 90 & .846 & \\
\hline & Total & 1.97 & 258 & .931 & & & & 1.96 & 270 & .876 & \\
\hline \multirow{4}{*}{ EPT } & comprehensibility & 2.00 & 86 & .894 & $.004^{*}$ & \multirow{4}{*}{ EPT } & \multirow{4}{*}{$\begin{array}{l}\text { comprehensibility } \\
\text { embarrassment } \\
\text { effectiveness } \\
\text { Total }\end{array}$} & 1.80 & 90 & .810 & \multirow[t]{4}{*}{$.000^{*}$} \\
\hline & embarrassment & 2.22 & 86 & 1.089 & & & & 2.13 & 90 & 1.104 & \\
\hline & effectiveness & 1.74 & 86 & .785 & & & & 1.52 & 90 & .502 & \\
\hline & Total & 1.99 & 258 & .948 & & & & 1.82 & 270 & .875 & \\
\hline \multirow{4}{*}{ ELT } & comprehensibility & 2.10 & 86 & .970 & .221 & \multirow{4}{*}{ ELT } & \multirow{4}{*}{$\begin{array}{l}\text { comprehensibility } \\
\text { embarrassment } \\
\text { effectiveness } \\
\text { Total }\end{array}$} & 2.04 & 90 & .935 & \multirow[t]{4}{*}{$.004^{*}$} \\
\hline & embarrassment & 2.28 & 86 & .916 & & & & 2.29 & 90 & .927 & \\
\hline & effectiveness & 2.03 & 86 & .951 & & & & 1.84 & 90 & .763 & \\
\hline & Total & 2.14 & 258 & .948 & & & & 2.06 & 270 & .894 & \\
\hline \multirow{4}{*}{ VMF } & comprehensibility & 2.19 & 86 & .964 & $.005^{*}$ & \multirow{4}{*}{ VMF } & \multirow{4}{*}{$\begin{array}{l}\text { comprehensibility } \\
\text { embarrassment } \\
\text { effectiveness } \\
\text { Total }\end{array}$} & 2.47 & 90 & .962 & \multirow[t]{4}{*}{$.000^{*}$} \\
\hline & embarrassment & 2.53 & 86 & 1.026 & & & & 2.79 & 90 & .954 & \\
\hline & effectiveness & 2.09 & 86 & .792 & & & & 2.16 & 90 & .833 & \\
\hline & Total & 2.27 & 258 & .948 & & & & 2.47 & 270 & .951 & \\
\hline \multirow{4}{*}{ RPT } & comprehensibility & 2.69 & 86 & 1.043 & .841 & \multirow{4}{*}{ RPT } & \multirow{4}{*}{$\begin{array}{l}\text { comprehensibility } \\
\text { embarrassment } \\
\text { effectiveness } \\
\text { Total }\end{array}$} & 2.51 & 90 & 1.104 & \multirow[t]{4}{*}{.782} \\
\hline & embarrassment & 2.78 & 86 & 1.011 & & & & 2.59 & 90 & .982 & \\
\hline & effectiveness & 2.73 & 86 & 1.056 & & & & 2.62 & 90 & 1.176 & \\
\hline & Total & 2.73 & 258 & 1.034 & & & & 2.57 & 270 & 1.087 & \\
\hline \multirow{4}{*}{ CLR } & comprehensibility & 3.08 & 86 & .997 & .196 & \multirow{4}{*}{ CLR } & \multirow{4}{*}{$\begin{array}{l}\text { comprehensibility } \\
\text { embarrassment } \\
\text { effectiveness } \\
\text { Total }\end{array}$} & 2.98 & 90 & 1.081 & \multirow[t]{4}{*}{.169} \\
\hline & embarrassment & 2.83 & 86 & .984 & & & & 2.70 & 90 & 1.033 & \\
\hline & effectiveness & 2.86 & 86 & 1.031 & & & & 2.73 & 90 & 1.110 & \\
\hline & Total & 2.92 & 258 & 1.007 & & & & 2.80 & 270 & 1.078 & \\
\hline
\end{tabular}

Significant at the 0.05 level

Note: 1 = strongly agree, $2=$ agree, $3=$ neutral, 4 = disagree, 5 = strongly disagree

A high mean indicates a less positive attitude and a low mean indicates a more positive attitude

Abbreviations: VSC stands for Visual Cues, EPT for Explicit Correction, ELT for Elicitation, VMF for Verbal Metalinguistic Feedback, RPT for Repetition, and CLR for Clarification Requests

\section{Assessments on the qualities of the different corrective feedback types by learning environment}

In comparison of learners' assessments on the qualities of the different corrective feedback types by learning environment or institutions, the results reveal that learners of Institutions A seem to have more concern on 'embarrassment' as compared to those of Institution B, at which the learners seem to have insignificant difference in their assessment of the qualities except for Explicit Correction and Verbal Metalinguistic Feedback. This seems to indicate that learners whose English Language awareness are high, are also much sensitive in terms of face-saving for all corrective feedback types. Such obvious sensitivity does not happen in Institution B, perhaps this is due to the state of mediocrity environment where learners are mediocre in the knowledge of English Language. Table 1.3 summarizes the results on comparison of learners' judgements on the qualities of all the corrective feedback types between Institution A and Institution B. 
Table 1.3 Mean scores, standard deviation and significance for correction type in relation to reaction type for respondents of Institutions A and B

\begin{tabular}{|c|c|c|c|c|c|c|c|c|c|c|c|}
\hline \multicolumn{6}{|c|}{ Respondents of Institution A } & \multicolumn{6}{|c|}{ Respondents of Institution B } \\
\hline $\begin{array}{l}\text { Cor. } \\
\text { Typ. }\end{array}$ & Evaluation Crit. & Mean & $\mathbf{N}$ & $\begin{array}{l}\text { Std. } \\
\text { Dev. }\end{array}$ & $\begin{array}{c}\text { p- } \\
\text { value }\end{array}$ & $\begin{array}{l}\text { Cor. } \\
\text { Typ. }\end{array}$ & Evaluation Crit. & Mean & $\mathbf{N}$ & $\begin{array}{l}\text { Std. } \\
\text { Dev. }\end{array}$ & $\begin{array}{c}\text { p- } \\
\text { value }\end{array}$ \\
\hline \multirow{4}{*}{ VSC } & comprehensibility & 1.82 & 88 & .824 & $.046 *$ & \multirow{4}{*}{ VSC } & \multirow{4}{*}{$\begin{array}{l}\text { comprehensibility } \\
\text { embarrassment } \\
\text { effectiveness } \\
\text { Total }\end{array}$} & 1.92 & 88 & .962 & \multirow[t]{4}{*}{.187} \\
\hline & embarrassment & 2.07 & 88 & .814 & & & & 2.18 & 88 & .977 & \\
\hline & effectiveness & 1.80 & 88 & .775 & & & & 1.99 & 88 & 1.00 & \\
\hline & Total & 1.89 & 264 & .811 & & & & 2.03 & $\begin{array}{c}26 \\
4\end{array}$ & .982 & \\
\hline \multirow{4}{*}{ EPT } & comprehensibility & 1.91 & 88 & .839 & $.004^{*}$ & \multirow{4}{*}{ EPT } & \multirow{4}{*}{$\begin{array}{l}\text { comprehensibility } \\
\text { embarrassment } \\
\text { effectiveness } \\
\text { Total }\end{array}$} & 1.89 & 88 & .877 & \multirow[t]{4}{*}{$.000^{*}$} \\
\hline & embarrassment & 2.15 & 88 & 1.088 & & & & 2.20 & 88 & 1.10 & \\
\hline & effectiveness & 1.69 & 88 & .764 & & & & 1.57 & 88 & .542 & \\
\hline & Total & 1.92 & 264 & .923 & & & & 1.89 & $\begin{array}{c}26 \\
4\end{array}$ & .907 & \\
\hline \multirow{4}{*}{ ELT } & comprehensibility & 2.12 & 88 & .980 & $.015 *$ & \multirow{4}{*}{ ELT } & \multirow{4}{*}{$\begin{array}{l}\text { comprehensibility } \\
\text { embarrassment } \\
\text { effectiveness } \\
\text { Total }\end{array}$} & 2.02 & 88 & .922 & \multirow[t]{4}{*}{.082} \\
\hline & embarrassment & 2.42 & 88 & .968 & & & & 2.15 & 88 & .851 & \\
\hline & effectiveness & 2.02 & 88 & .871 & & & & 1.85 & 88 & .851 & \\
\hline & Total & 2.19 & 264 & .952 & & & & 2.01 & $\begin{array}{c}26 \\
4\end{array}$ & .881 & \\
\hline \multirow{4}{*}{ VMF } & comprehensibility & 2.49 & 88 & .983 & $.002 *$ & \multirow{4}{*}{ VMF } & \multirow{4}{*}{$\begin{array}{l}\text { comprehensibility } \\
\text { embarrassment } \\
\text { effectiveness } \\
\text { Total }\end{array}$} & 2.17 & 88 & .937 & \multirow[t]{4}{*}{$.000^{*}$} \\
\hline & embarrassment & 2.65 & 88 & .898 & & & & 2.68 & 88 & 1.08 & \\
\hline & effectiveness & 2.16 & 88 & .843 & & & & 2.09 & 88 & .783 & \\
\hline & Total & 2.43 & 264 & .929 & & & & 2.31 & $\begin{array}{c}26 \\
4\end{array}$ & .977 & \\
\hline \multirow{4}{*}{ RPT } & comprehensibility & 2.80 & 88 & 1.105 & .878 & \multirow{4}{*}{ RPT } & comprehensibility & 2.40 & 88 & $\begin{array}{c}1.01 \\
2\end{array}$ & \multirow[t]{4}{*}{.675} \\
\hline & embarrassment & 2.88 & 88 & .969 & & & embarrassment & 2.49 & 88 & .994 & \\
\hline & effectiveness & 2.82 & 88 & 1.120 & & & effectiveness & 2.53 & 88 & 1.10 & \\
\hline & Total & 2.83 & 264 & 1.063 & & & Total & 2.47 & $\begin{array}{c}26 \\
4\end{array}$ & 1.03 & \\
\hline \multirow{4}{*}{ CLR } & comprehensibility & 3.24 & 88 & 1.028 & $.036^{*}$ & \multirow{4}{*}{ CLR } & comprehensibility & 2.82 & 88 & $\begin{array}{c}1.01 \\
2\end{array}$ & \multirow[t]{4}{*}{.491} \\
\hline & embarrassment & 2.89 & 88 & .915 & & & embarrassment & 2.64 & 88 & 1.08 & \\
\hline & effectiveness & 2.91 & 88 & 1.079 & & & effectiveness & 2.68 & 88 & 1.05 & \\
\hline & Total & 3.01 & 264 & 1.019 & & & Total & 2.71 & $\begin{array}{c}26 \\
4\end{array}$ & $\begin{array}{c}1.05 \\
0\end{array}$ & \\
\hline
\end{tabular}

* Significant at the 0.05 level

Note: $1=$ strongly agree, $2=$ agree, $3=$ neutral, $4=$ disagree, $5=$ strongly disagree

A high mean indicates a less positive attitude and a low mean indicates a more positive attitude

Abbreviations: VSC stands for Visual Cues, EPT for Explicit Correction, ELT for Elicitation, VMF for Verbal Metalinguistic Feedback, RPT for Repetition, and CLR for Clarification Requests

\section{Specific concern on the qualities of the corrective feedback types}

Based on all the results shown in Table 1.0, 1.1,1.2 and 1.3 it is obvious that the learners are very much aware of the different qualities or evaluation criteria for the different corrective feedback types. Although the assessment on the qualities are generally positive as depicted by the means for all the qualities in connection with all the corrective feedback types. The learners in the current study generally indicate that "embarrassment" is the most obvious quality of their concern compared to "comprehensibility" and "effectiveness", except for Clarification Requests in which "comprehensibility" is the most concerned qualities. For this type of corrective feedback, perhaps when a request to clarify the words uttered by a learner in the corrective move is addressed to him or her, it may be perceived as requesting for the meaning of the word. Thus, causes confusion. 


\section{Conclusion}

Errors in pronunciation may be corrected through several corrective feedback types, such as Explicit correction, Visual Cues, Clarification Request, Verbal Metalinguistic Feedback, Elicitation and Repetition. Every corrective feedback type has its own qualities that may be workable or otherwise for a learner. The purpose of this study has been to gauge the qualities of these corrective feedback types in terms of "comprehensibility", "effectiveness" and "embarrassment". Despite the generally positive assessments on the qualities for all the corrective feedback types, there has been a quite consistent concern on "embarrassment" particularly with regards to Explicit Correction and Verbal Metalinguistic Feedback with which "embarrassment" is a great concern at all levels of comparison, followed by Elicitation. The findings in the current study seems to strongly suggest that the three corrective feedback types may need much extended study with bigger population to ascertain a much clearer state of these corrective feedback types in relation to learners' perceptions and the way forward.

\section{References}

Abu Bakar, Z \& Abdullah, M. R. T. (2015). Importance of Correct Pronunciation in Spoken English: Dimension of Second Language Learners' Perspective. Pertanika Journal of Social Science and Humanities, 23(S), 143158 .

Agudo, M. \& de Dios, J. (2013). An investigation into how EFL learners emotionally respond to teachers' oral corrective feedback. Colombian Applied Linguistics Journal, 15(2), 265-278.

Celce-Murcia, M., Brinton, D. M., \& Goodwind, J. M. (1996). Teaching pronunciation: reference for teachers of English to speakers of other languages. Cambridge: Cambridge University Press.

Chomsky, N. (1959). Review of Verbal Behaviour by B.F.Skinner. Language, 35, 26-58.

Dalton, C., \& Seidlhofer, B. (2000). Pronunciation. Oxford: Oxford University Press.

Ellis, R. (2001). Investigating form-focused instruction. Language Learning, 51(Supplement 1), 1-46.

Ellis, R., Basturkmen, H., \& Loewen, S. (2001). Learner uptake in commnicative ESL lessons. Language Learning, $51(2), 281-318$.

Ellis, R. (2017). Oral corrective feedback in L2 Classrooms: What We Know So Far. In N. Hossein \& K. Eva (Eds.), Corrective Feedback in Second Language Learning and Teaching (pp.3-18). New York: Rouledge

Krashen, S. D. (1982). Principles and practice in second langauge acquisition. Englewood Clifts, NJ: Prentice-Hall.

Krashen, S. D. (1985). The input hypothesis: issues and implications. New York: Longman.

Krashen, S. D. (1994). The input hypothesis and its rivals. In N. Ellis (Ed.), Implicit and explicit learning of languages (pp. 45-77). London: Academic Press.

Levelt, W. J. M. (1989). Speaking: from intention to articulation. Cambridge, MA: MIP Press.

Lyster, R., \& Ranta, L. (1997). Corrective feedback and learner uptake: negotiation of form in communicative classrooms. Studies in Second Language Acquisition, 19, 37-66.

Murphy, J \& Baker, A.A. (2015). History of ESL pronunciation teaching. In M. Reed \& J.M.Levis (Eds), The Handbook of English Pronunciation (pp.36-65), United Kingdom: Wiley-Blackwell. 
Neri, A., Cucchiari, C., \& Strick, H. (2001). Effective feedback on L2 pronunciation in ASR-based CALL. Proceedings of the workshop on Computer Assisted Language Learning, Artificial Intelligence in Education Conference. San Antonio, Texas.

Poulos, A. \& Mahony, M. J. (2008). Effectiveness of feedback: the students' perspective. Assessment \& Evaluation in Higher Education, 33(2), 143-154.

Price, M., Handley, K., Millar, J., \& O’Donovan, B. (2010). Feedback: all that effort, but what is the effect? Assessment \& Evaluation in Higher Education, 35(3), 277-289.

Saito, K. \& Lyster, R. (2012). Effects of Form-Focused Instruction and Corrective Feedback on L2 Pronunciation Development of /r\{turned\}/ by Japanese Learners of English. Language Learning, 62(2),595-633.

Schmidt, R. (1990). The role of consciousness in second language learning. Applied Linguistics, 11, 129-158.

Vanosfadrani, A. D. \& Basturkment, H. (2009). The Effectiveness of Implicit and Explicit Error Correction on Learner's Performance. System, 37(1),82-98. 